Peralihan Hak... Oleh: A. Hasyim Nawawie

\title{
PERALIHAN HAK ATAS TANAH BERDASARKAN PEWARISAN PADA GOLONGAN II KARENA TANPA KETURUNAN
}

\author{
Oleh: \\ A.Hasyim Nawawie \\ Institut Agama Islam Negeri (IAIN) Tulungagung
}

\section{Abstract}

One reason for expiration of one's ownership of land is due to death. Due to the existence of this legal event resulting shift in wealth from the people who died, both material and inmaterial wealth to the heirs of the deceased. With the death of someone this then there will be the heir, the heir and wealth. Heir is the person who died and left property, while the heirs are entitled to the wealth of the people died. And possessions left behind could be immaterial and material, material wealth, among others, land, houses or other objects. Inheritance is a law governing the heritage property of someone who has died is given to the beneficiary, such as families and communities more right. Inheritance law in force in Indonesia there are three namely: Customary Inheritance Law, Inheritance Law and Inheritance Law Civil Islam. Each region has different laws according to which they profess kekerababatan system. Heir in group II under Article 854, 855, 856 and Article 857 of the Civil Code. According to Article 854 of class II legacy earned for own rights, whereas under Article 855 to Article 857 obtained due to switch places. Group II consists of father, mother and brothers heir.

Salah satu sebab berakhirnya kepemilikan seseorang atas tanah adalah karena kematian. Karena dengan adanya peristiwa hukum ini mengakibatkan adanya peralihan harta kekayaan dari orang yang meninggal, baik harta kekayaan material maupun immaterial kepada ahli waris orang yang meninggal tersebut. Dengan meninggalnya 
seseorang ini maka akan ada pewaris, ahli waris dan harta kekayaan. Pewaris adalah orang yang meninggal dunia dan meninggalkan harta kekayaan, sedangkan ahli waris adalah orang yang berhak atas harta kekayaan dari orang meninggal. Dan harta kekayaan yang ditinggalkan bisa immaterial maupun material, harta kekayaan material antara lain tanah, rumah ataupun benda lainnya. Hukum waris adalah suatu hukum yang mengatur peninggalan harta seseorang yang telah meninggal dunia diberikan kepada yang berhak, seperti keluarga dan masyarakat yang lebih berhak. Hukum waris yang berlaku di Indonesia ada tiga yakni: hukum waris adat, hukum waris Islam dan hukum waris perdata. Setiap daerah memiliki hukum yang berbeda-beda sesuai dengan sistem kekerabatan yang mereka anut. Ahli waris pada golongan II diatur dalam Pasal 854, 855, 856 dan Pasal 857 KUHPerdata. Menurut Pasal 854 warisan golongan II diperoleh karena haknya sendiri, sedangkan menurut Pasal 855 sampai Pasal 857 diperoleh karena pergantian tempat. Golongan II terdiri dari ayah, ibu serta saudara-saudara si pewaris.

Keywords: Transition Rights, Inheritance, Class II

\section{Pendahuluan}

Tanah merupakan salah satu faktor penting dalam kehidupan manusia. Baik sebagai sumber hidup maupun sebagai wadah secara pembangunan fisik untuk digunakan bagi sebesarbesar kemakmuran rakyat. Lebih-lebih di Indonesia yang sebagian besar penduduknya bermata pencaharian di sekitar pertanian. Fungsi tanah begitu penting dan mempunyai arti sendiri, sebab tanah merupakan modal bagi kehidupan suatu keluarga. Selain itu, tanah juga selalu digunakan untuk berbagai kegiatan manusia, seperti tempat tinggal, mendirikan bangunan, bahkan sampai manusia meninggal dunia membutuhkan tanah.

Adanya hubungan yang erat antara manusia dengan tanah, karena tanah merupakan tempat berpijak dan melakukan 
kelangsungan hidup sehari-hari. Maka manusia berlomba-lomba untuk menguasai dan memiliki bidang tanah yang diinginkan karena tanah mempunyai nilai ekonomis bagi segala aspek kehidupan manusia. Untuk menciptakan kemakmuran dan kesejahteraan rakyat seperti yang diinginkan bangsa Indonesia, maka permasalahan yang berkaitan dengan penggunaan, pemilikan penguasaaan dan peralihan hak atas tanah memerlukan perhatian yang khusus dalam peraturan perundangan.

Jaminan kepastian hukum mengenai penguasaan atau peralihan hak-hak atas tanah oleh seseorang, yang diperoleh dari warisan merupakan perpindahan suatu hak atas tanah kepada orang lain. Yang dimaksudkan dari peneliti di sini adalah kepemilikan hak atas tanah yang diperoleh dari pewaris kepada ahli waris. Maka perpindahan hak di atas berarti subjek hak yaitu pewaris dan ahli waris, perlu dilaksanakan peralihan hak untuk mendapatkan jaminan kepastian hukum kepemilikan hak atas tanah. Untuk menjamin kepastian hukum kepemilikan hak atas tanah warisan khususnya pada peralihan hak atas tanah warisan diatur dalam suatu peraturan perundang-undangan, khususnya diatur dalam Undang-undang Pokok Agraria (UUPA) dan diatur dalam Kitab Undang-Undang Hukum Perdata (selanjutnya disebut KUHPerdata) terjemahan dari Burgerlijk Wetboek (selanjutnya disebut BW) diterapkan dalam mengatur menyelesaikan urusan waris di Indonesia.

Hal ini juga berdasarkan pada ketentuan dalam pasal 1 Aturan Peralihan Undang-Undang Dasar 1945 hasil amandemen keempat yang dengan tegas mengatur bahwa segala peraturan perundang-undangan yang ada masih tetap berlaku selama belum diadakan yang baru, satu komunitas yang sama, dimungkinkan di dalamnya ada beberapa sistem hukum yang berlaku secara bersamaan, keberlangsungan pluralitas sistem hukum dapat memicu berbagai masalah dan ketegangan, namun 
ketegangan tersebut menjadikan hukum barat berkembang seiring dengan penerapannya dan menjadi acuan hukum yang mampu memecahkan beberapa konflik hukum.

Dasar hukum berlakunya BW di Indonesia adalah azas konkordansi dan Pasal 1 Aturan Peralihan UUD 1945. Sudikno Mertokusumo menambahkan bahwa para ahli mempersoalkan secara mendalam mengapa hukum Belanda masih berlaku di Indonesia dan sepanjang hukum tersebut tidak bertentangan dengan Pancasila, UUD 1945 tetap masih dibutuhkan dan diberlakukan. ${ }^{1}$

Masalah warisan di Indonesia dapat diselesaikan menurut hukum waris Barat, hukum waris Islam dan hukum waris adat. Hukum waris barat bersumber dari KUHPerdata terjemahan dari BW peninggalan Belanda. Hukum waris Islam bersumber dari firman Allah SWT dan Sunnah Rasul Muhammad SAW yang diyakini berlaku secara universal di seluruh belahan dunia, sumber lainnya adalah ijtihad alim ulama yang disesuaikan dengan budaya dan hukum lokal di Indonesia, menjadi pedoman bagi penduduk yang beragama Islam. Acuan berikutnya masalah waris di Indonesia adalah hukum waris adat yang bersumber dari adat dan kebiasaan masyarakat adat tertentu di Indonesia yang merupakan negara plural dan memiliki beragam adat yang berbeda.

Hukum Waris adalah suatu hukum yang mengatur peninggalan harta seseorang yang telah meninggal dunia diberikan kepada yang berhak, seperti keluarga dan masyarakat yang lebih berhak. Peralihan hak milik atas tanah diatur dalam Pasal 20 ayat 2 UUPA yaitu hak milik dapat beralih dan dialihkan kepada pihak lain.

1 Mas Anienda Tien, Hukum Perdata Dalam Sistim Hukum Nasional, dalam http://elerning. upnjatim.ac.iddiakses terakhir pada tanggal 1 Maret 2015. 
Pengertian tentang kata "beralih" adalah suatu peralihan hak yang dikarenakan pemilik hak telah meninggal dunia maka haknya dengan sendiri menjadi beralih kepada ahli warisnya. Pasal 20 ayat (2) UUPA menyatakan bahwa hak milik atas tanah dapat beralih dan dapat dialihkan. Peralihan hak milik atas tanah dapat terjadi karena perbuatan hukum dan peristiwa hukum. Peralihan hak milik atas tanah karena perbuatan hukum dapat terjadi apabila pemegang hak milik atas tanah dengan sengaja mengalihkan hak yang dipegangnya kepada pihak lain. Sedangkan peralihan hak milik atas tanah karena peristiwa hukum, terjadi apabila pemegang hak milik atas tanah meninggal dunia, maka dengan sendirinya atau tanpa adanya suatu perbuatan hukum disengaja dari pemegang hak, hak milik beralih kepada ahli waris pemegang hak.

Pewarisan hak milik atas tanah tetap harus berlandaskan pada ketentuan Undang-undang Pokok Agraria dan Peraturan Pelaksanaannya. Penerima peralihan hak milik atas tanah atau pemegang hak milik atas tanah yang baru haruslah berkewarganegaraan Indonesia sesuai dengan ketentuan pasal 9 Undang-undang Pokok Agraria dan pasal 21 ayat (1) UUPA bahwa warga Negara Indonesia tunggal saja yang dapat mempunyai hak milik, dengan tidak membedakan kesempatan antara laki-laki dan wanita yang mempunyai kesempatan yang sama untuk memperoleh suatu hak atas tanah serta untuk mendapat manfaat dan hasilnya, baik bagi diri sendiri maupun keluarganya.

Berdasarkan latar belakang di atas, maka penulis tertarik untuk melakukan penelitian dengan judul "Peralihan Hak atas Tanah Berdasarkan Pewarisan pada Golongan II Karena Tanpa Keturunan (Studi Di Kantor Pertanahan Kota Kediri)”. 


\section{Pembahasan}

\section{Tinjauan Pustaka}

Dalam Undang-undang Nomor 5 Tahun 1960 tentang Peraturan Dasar Pokok-pokok Agraria Pasal 16 ayat 1 menyebutkan Hak-hak atas tanah ialah :

1. Hak Milik,

2. Hak Guna Usaha,

3. Hak Guna Bangunan,

4. Hak Pakai,

5. Hak Sewa,

6. Hak Membuka Tanah,

7. Hak Memungut Hasil Hutan,

8. Hak-hak lain yang tidak termasuk dalam hak-hak tersebut di atas yang akan ditetapkan dengan undang-undang serta hakhak yang sifatnya sementara sebagai yang disebutkan dalam pasal 53.

Walaupun semua hak atas tanah yang disebut di atas memberikan kewenangan untuk mempergunakan tanah yang dihaki, tetapi sifat-sifat khusus haknya, tujuan penggunaan tanah dan batas waktu penguasaanya merupakan dasar perbedaan antara hak atas tanah yang satu dengan yang lain. Selain itu pemegang hak atas tanah juga dibebani berberapa kewajiban yang berkaitan dengan kepentingan masyarakat. Beberapa kewajiban yang harus dipenuhi pemegang hak atas tanah adalah:

1. Tanah mempunyai fungsi sosial

Yaitu apapun jenis dari hak atas tanah yang dikuasai, seseorang tidak diperbolehkan mempergunakan atau tidak mempergunakan tanah semata-mata hanya untuk kepentingan pribadi, apalagi kalau hal tersebut menimbulkan kerugian bagi masyakat lain.

2. Kewajiban memelihara tanah yang dihaki. Memelihara tanah, termasuk mengusahakan tingkat kesuburan tanah serta 
mencegah perbuatan yang mengakibatkan kerusakan pada tanah.

3. Karena kewajiban untuk mengelola tanah secara aktif. Setiap orang atau badan hukum yang memiliki hak atas tanah pertanian pada dasarnya diwajibkan atau mengusahakannya sendiri secara aktif.

4. Kewajiban untuk membayar pajak. Para pemilik tanah yang mengusahakan tanah diwajibkan membayar Pajak bumi Bangunan (PBB) sesuai dengan peraturan Undang-undang perpajakan yang berlaku.

5. Kewajiban untuk melakukan pendaftaran tanah.

Untuk memperoleh kepastian hukum dan memperoleh alat bukti yang kuat dalam bentuk sertifikat hak atas tanah harus melakukan pendaftaran tanah di kantor pertanahan setempat. Hak atas tanah yang wajib didaftarkan adalah hak milik, hak guna usaha, hak guna bangunan, hak pakai dan hak sewa. Di luar UUPA, hak tanggungan yang diatur dengan undang-undang Nomor 4 tahun 1996 wajib juga untuk didaftarkan. Dalam pendaftaran peralihan hak atas tanah karena hibah yang dimaksud dengan hak atas tanah ini adalah hak atas tanah dengan status hak milik.

Pengertian dari hak milik yaitu hak atas tanah yang "terkuat dan terpenuh". (Pasal 20 UUPA). Dijelaskan dalam penjelasan pasal tersebut, bahwa maksud pernyataan tersebut adalah untuk menunjukan, bahwa antara hak-hak atas tanah Hak Miliklah yang "ter"- (dalam arti “paling”) kuat dan “ter"-penuh. Yaitu mengenai tidak adanya batas waktu penguasaan tanahnya dan luas lingkup penggunaannya, yang meliputi baik untuk diusahakan atau digunakan sebagai tempat membangun sesuatu. $^{2}$

2 Boedi Harsono, Himpunan Peraturan-Peraturan Hukum Tanah (Jakarta : Djambatan, 2002), h. 290. 
Hak milik adalah hak turun temurun, terkuat dan terpenuh yang dapat dimiliki orang atas tanah, dengan memberi kewenangan untuk menggunakannya bagi segala macam keperluan selain waktu yang tidak terbatas, sepanjang tidak ada larangan untuk itu.

Pengertian hak atas tanah terdapat di dalam pasal 4 ayat (1) Undang-undang Pokok Agraria, yang menyatakan, "Atas dasar hak menguasai dari negara, sebagai yang dimaksud dalam Pasal 2 ditentukan adanya macam-macam hak atas permukaan bumi, yang disebut tanah, yang dapat diberikan kepada dan dipunyai orang-orang, baik sendiri maupun bersama-sama dengan orang orang lain serta badan-badan hukum".

Kewenangan terhadap hak atas tanah yang diberikan negara terbatas pada hak untuk mempergunakan tanahnya, sedangkan hak untuk mengelola benda-benda lain di dalam tanah, misalnya bahan-bahan mineral, minyak dan lain-lainnya tidak termasuk dalam pengertian hak yang diberikan oleh negara. Hak tersebut diatur secara khusus dalam undang-undang tentang ketentuan pokok pertambangan. ${ }^{3}$

Beberapa pendapat tentang pengertian dari hukum waris berdasarkan KUHPerdata:

a. Tan Thong Kie, "hukum waris (erfrecht) yaitu serangkaian ketentuan yang mengatur peralihan warisan seseorang yang meninggal dunia kepada seorang atau lebih". ${ }^{4}$

b. A. Pitlo, "hukum waris ialah kumpulan peraturan yang mengatur mengenai kekayaan karena matinya seseorang yaitu mengenai pemindahan kekayaan yang ditinggalkan oleh si mati dan akibat dari pemindahan ini bagi orang-orang yang

${ }^{3}$ K. Wantjik Saleh, Hak Anda Atas Tanah (Jakarta: Ghalia Indonesia, 1990), h. 15.

${ }^{4}$ Tan Thong Kie, Studi Notariat dan Serba-serbi Praktek Notaris, Cet. II (Jakarta: Ichtiar Baru Van Hoeve, 2011), h. 224. 
memperolehnya, baik dalam hubungan antara mereka dengan pihak ketiga". 5

c. D.M. Knol, "hukum waris mengatur ketentuan-ketentuan tentang perpindahan harta peninggalan dari orang yang telah meninggal, kepada ahli warisnya atau lebih". 6

d. J. Satrio, "hukum waris menurut para sarjana pada pokoknya adalah peraturan yang mengatur perpindahan kekayaan seseorang yang meninggal dunia kepada satu atau beberapa orang lain". 7

e. Abdulkadir Muhammad, "hukum waris adalah segala peraturan hukum yang mengatur tentang beralihnya harta warisan dari pewaris karena kematian kepada ahli waris atau orang yang ditunjuk". 8

Hukum waris KUHPerdata dalam pengaturannya tidak dibedakan antara anak laki-laki dan anak perempuan, antara suami dan istri. Semua mereka berhak mewaris, bagian anak laki-laki sama dengan bagian anak perempuan. Bagian seorang isteri atau suami sama dengan bagian anak jika dari perkawinan itu dilahirkan anak. Apabila si pewaris tidak mempunyai isteri dan keturunan maka ahli waris yang berhak mewaris harta si pewaris adalah orang tua dan saudara-saudara si pewaris.

Kenyataannya sering kali antara kepastian hukum terjadi benturan dengan kemanfaatan, atau antara keadilan dengan kepastian hukum, antara keadilan terjadi benturan dengan kemanfaatan. Sebaliknya kalau kemanfaatan masyarakat luas

${ }^{5}$ Erman Suparman, Intisari Hukum Waris Islam Indonesia (Bandung: Mandar Maju, 1995), h. 3.

6 Sudarsono, Hukum Waris dan Sistem Bilateral (Jakarta: Rineka Cipta, 1993), h. 11.

7 Hilam Hadikusumah, Hukum Waris Indonesia menurut Perundangan Hukum Adat, Hukum Agama Hindu-Islam (Bandung: Citra Aditya Bhakti, 1996), h. 5.

${ }^{8}$ Abdulkadir Muhammad, Hukum dan Penelitian Hukum (Bandung: Citra Aditya Bakti, 2004), h. 267. 
dipuaskan, perasaan adil bagi orang tertentu terpaksa harus dikorbankan.

Hukum sebagai pengemban nilai keadilan, dapat menjadi ukuran bagi adil dan tidaknya tata hukum. Maka dari itu, nilai keadilan juga menjadi dasar dari hukum sebagai hukum. Dengan demikian, keadilan memiliki sifat normatif sekaligus konstitutif bagi hukum. Dalam hal ini, keadilan menjadi landasan moral hukum dan sekaligus tolok ukur sistem hukum positif. Karenanya, kepada keadilanlah, hukum positif berpangkal. Sedangkan konstitutif, karena keadilan harus menjadi unsur mutlak bagi hukum. Artinya, hukum tanpa keadilan adalah sebuah aturan yang tidak pantas menjadi hukum.

Keadilan adalah tujuan hukum yang pertama dan utama, karena hal ini sesuai dengan hakikat atau ontologi hukum itu sendiri. Bahwa hukum dibuat untuk menciptakan ketertiban melalui peraturan yang adil, yakni pengaturan kepentingankepentingan yang saling bertentangan dengan seimbang sehingga setiap orang memperoleh sebanyak mungkin apa yang menjadi bagiannya. Bahkan dapat dikatakan dalam seluruh sejarah filsafat hukum selalu memberikan tempat yang istimewa kepada keadilan sebagai suatu tujuan hukum. ${ }^{9}$

Tujuan hukum atau dalam bentuk lain adalah putusan yang baik dan bijaksana dapat dipastikan akan mengandung tiga tujuan hukum di atas. Sebaliknya, putusan yang kurang baik hanya akan memuat satu tujuan hukum mengenyampingkan tujuan hukum yang lain.

Secara juridis dan ideologis, instansi penegak hukum dan aparat penegak hukum di Indonesia (tidak terkecuali dalam hal ini adalah BPN atau kantor pertanahan setempat) merupakan suatu kesatuan sistem yang terintegrasi dalam membangun satu misi penegakan hukum. Meskipun penegakan hukum secara prinsip adalah satu, namun secara substantif penegakan hukum,

\footnotetext{
${ }^{9}$ Ibid., h. 4.
} 
penyelesaian perkara akan melibatkan seluruh integritas kepribadian para aparat penegak hukum yang terlibat di dalamnya. Keberhasilan atau kegagalan para penegak hukum dalam melaksanakan tugasnya sebetulnya sudah dimulai sejak peraturan hukum dijalankan itu dibuat.

Norma hukum dikatakan berlaku secara filosofis apabila norma hukum itu memang bersesuaian dengan nilai-nilai filosofis yang dianut oleh suatu negara. Nilai filosofis negara Republik Indonesia terkandung dalam Pancasila sebagai "staatsfundamentalnorm". Dalam rumusan kelima sila Pancasila terkandung nilai-nilai religiusitas Ketuhanan Yang Maha Esa, humanitas kemanusiaan yang adil dan beradab, nasionalitas kebangsaan dalam ikatan berbhineka-tunggal-ikaan, soverenitas kerakyatan, dan sosialitas keadilan bagi segenap rakyat Indonesia. Dari kelima nilai-nilai filosofis tersebut tidak satupun yang boleh diabaikan atau malah ditentang oleh norma hukum yang terdapat dalam berbagai kemungkinan bentuk peraturan perundang-undangan dalam wadah Negara Kesatuan Republik Indonesia.

Norma hukum dengan daya ikatnya untuk umum dari pertimbangan bersifat teknis juridis berlaku apabila norma hukum sendiri memang ditetapkan sebagai norma hukum berdasarkan norma hukum yang lebih tinggi. Mengikat atau berlaku karena menunjukkan hubungan keharusan antara suatu kondisi dengan akibatnya. Ditetapkan sebagai norma hukum menurut prosedur pembentukan hukum yang berlaku dan ditetapkan sebagai norma hukum oleh lembaga yang memang berwewenang untuk itu. Maka norma hukum yang bersangkutan dapat dikatakan memang berlaku secara juridis.

Norma hukum berlaku secara politis apabila pemberlakuannya itu memang didukung oleh faktor-faktor kekuatan politik yang nyata. Keberlakuan politik ini berkaitan dengan teori kekuasaan (power theory) yang memberikan 
legitimasi pada keberlakuan suatu norma hukum semata-mata dari sudut pandang kekuasaan. Apapun wujudnya dan bagaimanapun proses pengambilan keputusan politik tersebut dicapainya sudah cukup untuk menjadi dasar legitimasi bagi keberlakuan norma hukum yang bersangkutan dari segi politik.

Norma hukum berlaku mengutamakan pendekatan yang empiris dengan mengutamakan beberapa pilihan criteria pengakuan (recognition theory), penerimaan (reception theory), faktisitas hukum. Hal itu menunjukkan, bahwa keadilan tidak hanya dapat diperoleh di pengadilan, tetapi lebih jauh dari itu. Karena keadilan yang sebenarnya muncul kesepakatankesepakatan yang dilakukan oleh para pihak yang bersengketa.

\section{Pembahasan}

Dasar hukum yang melandasi pelaksanaan peralihan hak atas tanah karena pewarisan sebagai berikut:

a. Undang-undang Nomor 5 Tahun 1960 tentang Peraturan dasar Pokok-Pokok Agraria;

b. Kitab Undang-undang Hukum Perdata ( KUHPerdata );

c. Undang-undang Nomor 28 Tahun 2009 tentang Pajak Daerah dan Retribusi Daerah;

d. Peraturan Pemerintah Nomor 24 Tahun 1997 tentang Pendaftaran Tanah;

e. Peraturan Presiden Nomor 10 Tahun 2006 tentang Badan Pertanahan Nasional;

f. Peraturan Menteri Negara Agraria/Kepala Badan Pertanahan Nasional Nomor 3 Tahun 1997 tentang Ketentuan pelaksanaan Peraturan Pemerintah Nomor 24 Tahun 1997 tentang Pendaftaran Tanah;

Salah satu sebab berakhirnya kepemilikan seseorang atas tanah adalah karena kematian. Karena dengan adanya peristiwa hukum ini mangakibatkan adanya peralihan harta kekayaan dari orang yang meninggal, baik harta kekayaan material maupun 
immaterial kepada ahli waris orang yang meninggal tersebut. Dengan meninggalnya seseorang ini maka akan ada pewaris, ahli waris dan harta kekayaan.

Pewaris adalah orang yang meninggal dunia dan meninggalkan harta kekayaan, sedangkan ahli waris adalah orang yang berhak atas harta kekayaan dari orang meninggal. Dan harta kekayaan yang ditinggalkan bisa immaterial maupun material, harta kekayaan material antara lain tanah, rumah ataupun benda lainnya.

Hukum waris adalah suatu hukum yang mengatur peninggalan harta seseorang yang telah meninggal dunia diberikan kepada yang berhak, seperti keluarga dan masyarakat yang lebih berhak. Hukum waris yang berlaku di Indonesia ada tiga yakni: hukum waris adat, hukum waris Islam dan hukum waris perdata. Setiap daerah memiliki hukum yang berbedabeda sesuai dengan sistem kekerabatan yang mereka anut.

Peralihan hak atas tanah diatur dalam Pasal 20 ayat 2 UUPA yaitu hak milik dapat beralih dan dialihkan kepada pihak lain. Pengertian tentang kata "beralih" adalah suatu peralihan hak yang dikarenakan pemilik hak telah meninggal dunia maka haknya dengan sendiri menjadi beralih kepada ahli warisnya. Pasal 20 ayat (2) UUPA menyatakan bahwa hak milik atas tanah dapat beralih dan dapat dialihkan. Peralihan hak atas tanah dapat terjadi karena perbuatan hukum dan peristiwa hukum. Peralihan hak milik atas tanah karena perbuatan hukum dapat terjadi apabila pemegang hak milik atas tanah dengan sengaja mengalihkan hak yang dipegangnya kepada pihak lain. Sedangkan peralihan hak milik atas tanah karena peristiwa hukum, terjadi apabila pemegang hak milik atas tanah meninggal dunia, maka dengan sendirinya atau tanpa adanya suatu perbuatan hukum disengaja dari pemegang hak, hak milik beralih kepada ahli waris pemegang hak. 
Menurut ketentuan Peraturan Pemerintah Nomor 10 Tahun 1961 junto Peraturan Pemerintah Nomor 24 Tahun 1997 tentang Pendaftaran Tanah, yang berhak menerima warisan wajib meminta pendaftaran peralihan hak tersebut dalam jangka waktu 6 (enam) bulan sejak meninggalnya orang yang semula mempunyai hak milik tersebut dengan tidak melanggar ketentuan bahwa menerima hak milik atas tanah harus sesuai dengan Undang-undang Pokok Agraria Pasal 21.

Kemudian berdasarkan pengamatan penulis selama mengadakan penelitian di Kantor Pertanahan Kota Kediri bahwa untuk peralihan hak milik atas tanah berdasarkan warisan, sebenarnya peralihan hak itu sudah terjadi setelah para ahli waris membuat surat keterangan ahli waris, karena berdasarkan wawancara penulis dengan bapak Leonel Orleans Da Luz kepala sub seksi sengketa dan konflik pertanahan di kantor pertanahan Kota Kediri, di dalam surat keterangan ahli waris itu sudah menyebutkan adanya peralihan harta dari pewaris ke ahli waris hanya saja secara yuridis belum bisa dikatakan kuat secara hukum karena belum didaftarkan peralihannya ke kantor pertanahan.

Ahli waris pada golongan II diatur dalam Pasal 854, 855, 856 dan Pasal 857 KUHPerdata. Menurut Pasal 854 warisan golongan II diperoleh karena haknya sendiri, sedangkan menurut pasal 855 sampai Pasal 857 diperoleh karena pergantian tempat. Golongan II terdiri dari ayah, ibu serta saudara-saudara si pewaris. Hal ini terjadi apabila si pewaris tidak memiliki anak, suami atau isteri.

Adapun pembagian harta warisan pada golongan II sebagai berikut:

a. Ayah, ibu mendapat $1 / 3$ bagian, sedangkan sisanya untuk saudara, baik laki-laki maupun perempuan. 
b. Ayah, ibu mendapat $1 / 4$ bagian jika pewaris meninggalkan lebih dari satu saudara. Sisanya $3 / 4$ dibagikan kepada saudaranya.

c. Ayah atau ibu (salah satu telah meninggal) dan pewaris meninggalkan satu orang saudara, maka bagian ayah atau ibu adalah $1 / 4$ bagian.

d. Ayah atau ibu (salah satu telah meninggal) dan pewaris meninggalkan 2 orang saudara, baik laki-laki maupun perempuan, maka ayah atau ibu mendapat $1 / 3$ bagian.

e. Ayah atau ibu (salah satu telah meninggal), pewaris meninggalkan lebih dari 2 saudara laki-laki atau perempuan, maka bagian ayah atau ibu adalah $1 / 4$ bagian.

f. Bila tidak memiliki ayah atau ibu, maka seluruh harta peninggalannya menjadi hak seluruh saudara si pewaris.

Kebijakan pertanahan dalam pelaksanaan hukum untuk menjalankan peralihan hak atas karena pewarisan berdasarkan kesepakatan para ahli waris pada golongan II yang tidak sesuai dengan aturan yang berlaku tidak akan mungkin bekerja dalam ruang hampa. Itulah sebabnya hukum pertanahan dalam pelaksanaan peralihan hak atas tanah karena pewarisan ini sesungguhnya dalam realitasnya berfungsi sebagai faktor pengintegrasian masyarakat. Sebagai pengatur sosial, hukum harus menjalani suatu proses yang panjang dan melibatkan berbagai aktivitas dengan kualitas yang berbedabeda dalam proses pembuatan hukum dan proses implementasi hukum. Proses pembuatan hukum itu sesungguhnya mengandung pengertian yang sama dengan istilah proses pembuatan Undang-undang.

Terwujudnya kepastian hukum dalam pendaftaran sertifikat hak atas tanah tidak lepas dari faktor kekurangan dalam substansi aturan pertanahan, disinkronisasi peraturan yang ada. Secara normatif, kepastian hukum memerlukan tersedianya perangkat aturan perundang-undangan yang secara 
operasional mampu mendukung pelaksanaannya. Secara empiris, keberadaan peraturan-peraturan itu dilaksanakan secara konsisten dan konsekuen oleh sumber daya manusia pendukungnya.

Tujuan hukum bukan hanya keadilan, tetapi juga kepastian hukum dan kemanfaatan. Pemenuhan keadilan dalam suatu peraturan perundang-undangan belum cukup karena masih memerlukan syarat kepastian hukum. Kepastian hukum akan tercapai bila suatu peraturan dirumuskan secara jelas, sehingga tidak menimbulkan penafsiran yang berbeda-beda serta tidak terjadi tumpang tindih antara peraturan yang ada, baik secara vertikal maupun horizontal. Mewujudkan sistem hukum yang baik akan menjadi sebuah hal yang sulit jika substansi aturan yang mendasarinya terdapat kesimpangsiuran akibat ketidaksinkronan aturan yang ada.

Secara juridis dan ideologis, instansi penegak hukum dan aparat penegak hukum di Indonesia (tidak terkecuali dalam hal ini adalah BPN atau kantor pertanahan setempat) merupakan suatu kesatuan sistem yang terintegrasi dalam membangun satu misi penegakan hukum. Meskipun penegakan hukum secara prinsip adalah satu, namun secara substantif penegakan hukum, penyelesaian perkara akan melibatkan seluruh integritas kepribadian para aparat penegak hukum yang terlibat di dalamnya. Keberhasilan atau kegagalan para penegak hukum dalam melaksanakan tugasnya sebetulnya sudah dimulai sejak peraturan hukum dijalankan itu dibuat.

Norma hukum dikatakan berlaku secara filosofis apabila norma hukum itu memang bersesuaian dengan nilai-nilai filosofis yang dianut oleh suatu negara. Nilai filosofis negara Republik Indonesia terkandung dalam Pancasila sebagai "staatsfundamentalnorm". Dalam rumusan kelima sila Pancasila terkandung nilai-nilai religiusitas Ketuhanan Yang Maha Esa, humanitas kemanusiaan yang adil dan beradab, soverenitas 
kerakyatan, dan sosialitas keadilan bagi segenap rakyat Indonesia. Dari kelima nilai-nilai filosofis tersebut tidak satupun yang boleh diabaikan atau malah ditentang oleh norma hukum yang terdapat dalam berbagai kemungkinan bentuk peraturan perundang-undangan dalam wadah Negara Kesatuan Republik Indonesia.

Langkah-langkah Kantor Pertanahan Kota Kediri dalam mengatasi hambatan peralihan hak atas tanah karena pewaris pada golongan II karena tanpa keturunan, berdasarkan wawancara dengan pejabat di lingkungan BPN Kota Kediri, yaitu sebagai berikut :

1. Langkah-langkah dalam menangani kendala yang disebabkan oleh masyarakat antara lain :

Memberikan penyuluhan dan menerbitkan brosur-brosur tentang pentingnya pelaksanaan peralihan hak atas tanah dari warisan sehingga ahli waris mendapat kepastian hukum dan menumbuhkan kesadaran masyarakat betapa pentingnya sertifikat. Penyuluhan merupakan jalan terbaik, karena pihak yang berwenang dalam hal ini kantor pertanahan dapat melakukan pendekatan, secara langsung dari masyarakat dengan adanya pendekatan dari kantor pertanahan menjadi positif sehingga dapat membantu proses pendaftaran dan persertifikatan.

2. Langkah-langkah dalam menangani kendala yang disebabkan oleh kantor pertanahan, antara lain :

a. Dengan memberikan seminar-seminar dan wawasan kepada petugas-petugas di Kantor Pertanahan Kota Kediri tentang hukum waris sesuai dengan ketentuan perundangundangan yang berlaku.

b. Kantor Pertanahan Kota Kediri berusaha membenahi administrasi karena sebagai pengorganisasian sumber daya manusia untuk mencapai tujuan. 


\section{Penutup}

Konsep peralihan hak atas tanah berdasarkan pewarisan pada golongan II karena tanpa keturunan terdapat 3 konsep yaitu:

a. Konsep ideal peralihan hak atas tanah berdasarkan pewarisan. Norma hukum berlaku mengutamakan pendekatan yang empiris dengan mengutamakan beberapa pilihan kriteria pengakuan (recognition theory), penerimaan (reception theory), faktisitas hukum. Hal itu menunjukkan, bahwa keadilan tidak hanya dapat diperoleh di pengadilan, tetapi lebih jauh dari itu. Karena keadilan yang sebenarnya muncul kesepakatan-kesepakatan yang dilakukan oleh para pihak yang bersengketa.

b. Konsep existing, implementasi dan penegakan hukum pada nilai-nilai dasar hukum. Tujuan hukum bukan hanya keadilan, tetapi juga kepastian hukum dan kemanfaatan. Pemenuhan keadilan dalam suatu peraturan perundangundangan belum cukup karena masih memerlukan syarat kepastian hukum. Kepastian hukum akan tercapai bila suatu peraturan dirumuskan secara jelas, sehingga tidak menimbulkan penafsiran yang berbeda-beda serta tidak terjadi tumpang tindih antara peraturan yang ada, baik secara vertikal maupun horizontal. Mewujudkan sistem hukum yang baik akan menjadi sebuah hal yang sulit jika substansi aturan yang mendasarinya terdapat kesimpangsiuran akibat ketidaksinkronan aturan yang ada

c. Konsep yang ditawarkan, langkah-langkah Kantor Pertanahan Kota Kediri dalam mengatasi hambatan peralihan hak atas tanah karena pewarisan pada golongan II karena tanpa keturunan. Langkah-langkah dalam menangani kendala yang disebabkan oleh masyarakat yaitu dengan memberikan penyuluhan dan menerbitkan brosur-brosur tentang pentingnya pelaksanaan peralihan hak atas tanah dari warisan 
sehingga ahli waris mendapat kepastian hukum dan menumbuhkan kesadaran masyarakat betapa pentingnya sertifikat. Penyuluhan merupakan jalan terbaik, karena pihak yang berwenang dalam hal ini Kantor Pertanahan dapat melakukan pendekatan, secara langsung dari masyarakat dengan adanya pendekatan dari kantor pertanahan menjadi positif sehingga dapat membantu proses pendaftaran dan persertifikatan, dan bagi Kantor Pertanahan Kota Kediri memberikan seminar-seminar dan wawasan kepada petugaspetugas di Kantor Pertanahan Kota Kediri tentang hukum waris sesuai dengan ketentuan perundang-undangan yang berlaku maka akan tercipta SDM yang mengerti betul tentang hukum waris yang berlaku.

Pelaksanaan peralihan hak atas tanah karena pewarisan pada golongan II karena tanpa keturunan dapat dilaksanakan dengan pembagian sesuai dengan Pasal 854, 855, 856 dan Pasal 857 KUHPerdata dan juga dapat dilaksanakan berdasarkan kesepakatan antara ahli waris dengan dibuktikan dengan akta kesepakatan pembagian hak bersama yang dibuat dihadapan Notaris. Sehingga ahli waris berdasarkan kesepakatan bersama dapat membagi sendiri hak bagian masing-masing dari harta warisan tersebut. 


\section{DAFTAR PUSTAKA}

Hadikusumah, Hilam. Hukum Waris Indonesia menurut

Perundangan Hukum Adat, Hukum Agama HinduIslam. Bandung: Citra Aditya Bhakti, 1996.

Harsono, Boedi. Himpunan Peraturan-Peraturan Hukum Tanah. Jakarta: Djambatan, 2002.

Kie, Tan Thong. Studi Notariat dan Serba-serbi Praktek Notaris, Cet. II. Jakarta: Ichtiar Baru Van Hoeve, 2011.

Muhammad, Abdulkadir. Hukum dan Penelitian Hukum. Bandung: Citra Aditya Bakti, 2004.

Saleh, K. Wantjik. Hak Anda Atas Tanah. Jakarta: Ghalia Indonesia, 1990.

Sudarsono. Hukum Waris dan Sistem Bilateral. Jakarta: Rineka Cipta, 1993.

Suparman, Erman. Intisari Hukum Waris Islam Indonesia. Bandung: Mandar Maju, 1995.

Tien, Mas Anienda. Hukum Perdata Dalam Sistim Hukum Nasional, dalam http://elerning. upnjatim.ac.iddiakses terakhir pada tanggal 1 Maret 2015. 